\title{
Analisis kesejahteraan petani padi di Kecamatan Air Hangat Timur Kabupaten Kerinci
}

\author{
Nanda Pratama*; Zulfanetti; Etik Umiyati \\ Prodi Magister Ilmu Ekonomi Program Pascasarjana Universitas Jambi \\ *E-mail korespondensi:nandaparatama15@gmail.com
}

\begin{abstract}
This research was conducted at Kerinci Regency, Air Hangat Timur sub-district, the largest rice harvesting area in Jambi Province. In this Air Hangat Timur sub-district area, the communities still use rice fields to cultivate rice as the primary commodity. This study aimed to determine rice farmers' welfare level in the Air Hangat Timur sub-district and determine the factors that affect the welfare of rice farmers based on predetermined indicators. This study used a quantitative descriptive analysis method, with the total sample used being 98 farmers from the entire population consisted 3531 rice farmers in Air Hangat Timur sub-district. Analyzing and testing the data, the researcher first carried out the classical assumption test using SPSS by obtaining the results of an Adjusted $R$ square value of 0.848. It can be concluded that the independent variable used can explain $84.8 \%$ of the dependent variable. The remaining $15.2 \%$ is outside the variable in use. The majority of rice farmers in the Air Warm Timur Subdistrict are not poor. This can be seen from the per capita income level of Rp. 5,053,227 per year, while 9\% of farmer families are classified as inferior if added up separately. According to the criteria of the Directorate of Land Use Rights, the remaining farmers in Air Warm Timur District are not in poor condition.
\end{abstract}

Keywords: Welfare, Income, Farmers

\begin{abstract}
Abstrak
Penelitian ini dilaksanakan di Kabupaten Kerinci, Kecamatan Air Hangat Timur yang meruapkan daerah panen padi terluas di Provinsi Jambi. Kecamatan Air Hangat Timur merupakan daerah yang masih menjadikan sawah untuk bercocok tanam padi sebagai komoditas andalannya. Adapun tujuan dari penelitian ini untuk mengetahui tingkat kesejahteraan petani padi di Kecamatan Air Hangat Timur dan mengetahui faktor-faktor yang mempengaruhi kesejahteraan petani padi berdasarkan indikator yang telah di tetapkan. Penelitian ini menggunakan jenis metode analisis deskriptif kuantitatif, dengan jumlah sample yang di gunakakn sebanyak 98 orang petani dari besaran populasi petani padi di kecamatan Air Hangat Timur sebesar 3531 petani padi. Analisa dan pengujian data peneliti terlebih dahulu melakukan uji asumsi klasik dengan menggunkan SPSS dengan memperolah hasil nilai Adjusted $\mathrm{R}$ square sebesar 0,848 bisa kita tarik kesimpulan bahwa 84,8\% variabel dependen dapat di jelaskan oleh variabel independen yang digunakan yang sisanya $15,2 \%$ berada di luar variabel yang digunakan. Petani padi di Kecamatan Air Hangat Timur mayoritas berada dalam keadaan tidak miskin, hal ini dilihat dari tingkat pendapatan perkapita sebesar Rp 5.053.227 pertahunnya, adapun jika dijumlahkan secara terpisah sebanyak 9\% keluarga petani tergolong dalam keadaan miskin selebihnya petani di Kecamatan Air Hangat Timur berada dalam keadaan tidak miskin, sesuai dengan kriteria Direktorat Hak Guna Tanah dan kriteria Sayogyo.
\end{abstract}

Kata kunci: Kesejahteraan, Pendapatan, Petani 


\section{PENDAHULUAN}

Badan Penyuluhan dan Pengembangan Sumber Daya Manusia (BPPSDM) Kementerian Pertanian dalam rencana strategisnya 2015-2019, pembangunan pertanian diharpakan mampu mendukung serta mencapai apa yang di targetkan oleh pembangunan nasional, diharapkan mampu menciptakan pertanian yang maju, mandiri, adil, bermartabat dan makmur di Indonesia. Berdasarkan hal ini, bisa kita lihat bahwa pemerintah dalam hal ini memberikan ruang gerak pembangunan perekonomian nasional didasarkan pada pembangunan pertanian (Kementan, 2019).

Jika melihat dari tujuan yang di paparkan di atas ini membuktikan untuk mencapai target pembangunan nasional, jika kita melihat kebelakang selama ini sektor pertanian menjadi salah satu penentu utama motor penggerak. Sektor pertanian selama ini menjadi salah satu sektor paling utama dalam berkontribusi dalam menyumbang devisa Negara (Virianita et al., 2019). Sektor pertanian di dalam Produk Domestik Bruto (PDB) Indonesia berkontribusi sebanyak $19,67 \%$ dilihat dari Pusat Data dan Informasi Kementerian Pertanian, hal ini memberikan gambaran bahwa adanya kemajuan serta keberhasilan sektor pertanian dalam hal pangan (Kementan, 2019).

Pemerintah dalam usaha-usahanya untuk menciptakan swasembada pangan khususnya padi, kita rasanya belum move on terhadap fakta sejarah masa lalu kita dengan swasembada pangan pada era orde baru yang mana juga berdampak pada kesejahteraan rumah tangga petani yang mana sektor pendapatannya meningkat. Keberhasilan tersebut membuktikan adanya keberpihakan nyata pemerintah terhadap petani hal ini terlihat pada kegiatan bimbingan terhadap petani sebagai upaya dalam memberikan pemahaman serta wawasan dalam hal pertanian, aksi nyata dalam hal kebijakan terlihat pada distribusi pupuk bersubsidi, relatif stabilnya harga pada saat itu. Pendapatan disini sangatkan menentukan kemampuan manusia dalam memenuhi kebutuhan primer, sekunder, dan tersier, logikanya jika harga kebutuhan meningkat tidak dukung oleh pendapatan yang memadai, akan berdampak pada tingkat kesejahteraan akan menurun (Dwijatenaya, 2017).

Sektor pertanian di Indonesia yang paling dominan dalam menyerap tenaga kerja sebagian besar rumah tangga terutama masyarakat perdesaan. Menurut Husein (Budiarti \& Muflikhati, 2013), sektor pertanian sering di pandang sebelah mata padahal secara kontribusi mempunyai peran yang sangat urgen bagi lapangan kerja terutama masyarakat desa, Jika pemerintah serius dalam melihat tingkat kesejahteraan dan mampu merencanakan dengan serius.

Di Provinsi Jambi mayoritas kabupaten kota hampir tidak terdapat perbedaan pada kehidupan antar masyarakat taninya. Persoalan-persoalan sosial-ekonomi yang dihadapi masyarakat tani tidak jauh berbeda. Mereka tetap memiliki tempat tinggal di rumah yang seadanya, kesulitan dalam memenuhi berbagai kebutuhan konsumsi, meskipun di wilayah yang sama terdapat masyarakat yang begitu sejahtera dimana dinilai karena cukup mampu dalam memenuhi berbagai kebutuhan hidupnya.

Dari data diatas kita dapat melihat luas panen terluas masih berada di Kabupaten Kerinci dengan luas panen sebesar 22.866 Ha, disusul oleh Kabupaten Tanjung Jabung Timur dengan luas panen 20.393 Ha dan terkecil dimiliki oleh Kota Jambi dengan luas panen yaitu 1.539 Ha. Sedangkan tingkat produktivitas Kabupaten Kerinci juga menduduki posisi tertinggi dengan jumlah produktivitas padi sebanyak 104,521 (ton/ha) terbanyak di Provinsi. Terlihat bahwa kabupaten kerinci mayoritas penduduknya memiliki pekerjaan sebagai petani baik di sawah maupun berkebun.

Kecamatan Air Hangat Timur yaitu suatu kecamatan yang ada di Kabupaten Kerinci. Kerinci merupakan Kabupaten dengan sentra Padi di Provinsi Jambi. Ini terlihat dari data table di bawah ini: 
Tabel 1. Menggambarkan keadaan pertanian khususnya Padi di Kabupaten/Kota di Provinsi Jambi, 2018

\begin{tabular}{lccc}
\hline \multicolumn{1}{c}{ Kabupaten } & $\begin{array}{c}\text { Luas Panen } \\
\text { (Ha) }\end{array}$ & $\begin{array}{c}\text { Produksi } \\
\text { (Ton) }\end{array}$ & $\begin{array}{c}\text { Produktivitas } \\
\text { (Ton/ha) }\end{array}$ \\
\hline Kerinci & 22886 & 45,67 & 104.521 \\
Merangin & 10098 & 41,58 & 41.984 \\
Sarolangun & 6336 & 31,97 & 20.256 \\
Batanghari & 11831 & 42,32 & 50.074 \\
Muaro Jambi & 11991 & 32,58 & 39.065 \\
Tanjabtim & 20393 & 35,81 & 73.018 \\
Tanjabbar & 14752 & 44,33 & 65.395 \\
Tebo & 6598 & 53,80 & 35.447 \\
Muaro Bungo & 5939 & 45,53 & 27.038 \\
Kota Jambi & 1539 & 42,38 & 6.522 \\
Sungai Penuh & 6054 & 60,62 & 36.7 \\
\hline Jumlah & $\mathbf{1 1 8} \mathbf{4 0 8}$ & $\mathbf{4 7 7 , 5 9}$ & $\mathbf{5 0 0 . 0 2 1}$ \\
Rata-rata & $\mathbf{1 0 ~ 7 6 4}$ & $\mathbf{4 3 , 4 1}$ & $\mathbf{4 5 . 4 5 6}$ \\
\hline
\end{tabular}

Sumber : Badan Pusat Statistik Provinsi Jambi(diolah)

Sedangkan berdasarkan observasi awal ditemukan bahwa sebagian besar masyarakat petani di Air Hangat Timur masih berada pada kondisi kesulitan dalam memenuhi kebutuhan hidup mereka sehingga bisa dikatakan belum sejahtera. Oleh karena itu untuk Kecamatan Air Hangat Timur juga perlu diteliti mengingat Kecamatan ini terdiri dari 25 desa dimana terdapat banyak masyarakat yang memiliki pekerjaan yang mayoritasnya Petani Padi Sawah.

Dari problema di atas yang telah diuraikan, maka peneliti merumuskan beberapa rumusan masalah di antaranya, bagaimana karakteristik sosial ekonomi Petani padi di Kecamatan Air Hangat Timur. Kemudian, Bagaimana tingkat Kesejahteraan Petani padi di Kecamatan Air Hangat Timur. Dan Faktor-faktor apakah yang mempengaruhi Kesejahteraan Petani padi di Kecamatan Air Hangat Timur.

Tujuan dilakukannya penelitian ini adalah yang pertama untuk menganalisis karakteristik sosial ekonomi petani padi di kecamatan air hangat timur. Kedua, Untuk Menganalisis tingkat kesejahteraan Petani padi di Kecamatan Air Hangat Timur. Ketiga, Untuk Menganalisis Faktor-faktor yang mempengaruhi kesejahteraan Petani padi di Kecamatan Air Hangat Timur.

\section{METODE}

\section{Jenis data dan sumber data}

Data primer dan data sekunder merupakan data yang digunakan dalam melengkapi penelitian ini. Data primer disini berasal dari hasil responden (sampel) dari penyebaran kuesioner dengan tujuan petani padi di Kecamatan Air Hangat Timur. Data Primer bersumber dari Masyarakat petani padi di kecamatan air hangat timur. Data Sekunder bersumber dari dari BPS, bahan pustaka, literatur, penelitian terdahulu, buku, dan media internet. 


\section{Metode analisis}

Metode analisis yang digunakan dalam penelitian ini adalah analisis deskriptif kualitatif dan kuantitatif. analisis deskriptif digunakan untuk menggambarkan variabel apa saja yang mempengaruhi kesejahteraan petani padi di Kecamatan Air Hangat Timur. Sedangkan analisis kuantitatif digunakan Analisis ini bertujuan untuk mendapatkan hasil dari ukuran besaran pengaruh variabel bebas terhadap variabel terikat.

\section{Alat analisis data}

untuk menjawab permasalahan pada penelitian ini yaitu dengan menggunakan teknik analisis deskriptif persentase diharapkan mampu memberikan gambaran seberapa besar pengaruh variabel independen terhadap variabel dependen. Menggunakan rumus:

$$
\begin{array}{ll}
\Pi & =\mathrm{TR}-\mathrm{TC} \\
\mathrm{TR} & =\mathrm{P} \times \mathrm{Q} \\
\mathrm{TC} & =\mathrm{TFC}+\mathrm{TVC}
\end{array}
$$

Keterangan :

$$
\begin{array}{ll}
\pi & =\text { Keuntungan } \\
\text { TR } & =\text { Total Penerimaan (Rp) } \\
\text { TC } & =\text { Total Biaya (Rp) } \\
\mathrm{P} & =\text { Harga Jual } \\
\mathrm{Q} & =\text { Hasil Panen }
\end{array}
$$

Untuk menjawab perumusan masalah ketiga dengan menggunkan metode analisis regresi linear berganda dengan persamaan:

$$
\mathbf{Y}=\alpha+\beta \mathbf{X}_{1}+\beta \mathbf{X}_{2}+\beta \mathbf{X}_{3}+\beta \mathbf{X}_{4}+\mathrm{e}
$$

Keterangan :

$\mathrm{Y}=$ Kesejahteraan

$\alpha \quad=$ Konstanta

$\beta_{1,2,3,4}=$ Koefisien regresi

$\mathrm{X}_{1} \quad=$ Pendidkan

$\mathrm{X}_{2} \quad=$ Tanggungan Keluarga

$\mathrm{X}_{3} \quad=$ Hasil Panen

$\mathrm{X}_{4} \quad=$ Modal

Pengujian di dalam penelitian ini dengan menggunakan aplikasi SPSS baik dalam uji secara simultan dan parsial.

\section{HASIL DAN PEMBAHASAN}

\section{Kondisi sosial}

Dalam menganalisis karakteristik sosial ekonomi petani padi di Kecamatan Air Hangat Timur Kabupaten Kerinci peneliti menyimpulkan dari hasil peneilitan bahwa petani padi rata-rata berusia 47 tahun dengan tingkat pendidikan rata-rata telah menamatkan tingkat SLTP. Jika melihat dari luas lahan yang dimiliki petani padinya ratarata mempunyai luas lahan yang dikelola sebesar $0,4 \mathrm{Ha}$ dengan status ada yang disewa dan milik sendiri. Dalam mengelola usaha padi ini mayoritas sebesar $85 \%$ petani padi menggunakan benih milik sendiri jika hasil yang diperolah pada panen sebelumnya dikatagorikan berhasil. Sedangkan untuk tanggungan keluarga rata-rata petani padi di Kecamatan Air Hangat Timur berjumlah 2,4 orang. 


\section{Kondisi ekonomi}

Kesejahteraan petani padi di Kabupaten Kerinci Kecamatan Air Hangat Timur berdasarkan kriteria Direktorat Hak Guna Tanah dan kriteria kemiskinan Sayogyo diperolah hasil setelah dilakukan pengolahan data yaitu rata-rata petani padi di Kabupaten Kerinci Kecamatan Air Hangat Timur berada dalam kondisi tidak miskin berdasarkan dua indikator pengukuran diatas dengan pendapatan perkapita rata-rata $\mathrm{Rp}$ 5.053.227.

\section{Analisis faktor-faktor yang mempengaruhi tingkat kesejahteraan petani padi}

Dalam mencari dan menganalisis faktor-faktor yang mempengaruhi tingkat kesejahteraan petani padi di Kecamatan Air Hangat Timur peneliti menggunakan metode analisis regresi linear berganda, adapun dalam penelitian ini peneliti menggunakan empat variabel diantaranya yaitu variabel pendidikan yang penulis jadikan sebagai variabel $\left(\mathrm{X}_{1}\right)$, tanggungan keluarga $\left(\mathrm{X}_{2}\right)$, hasil panen $\left(\mathrm{X}_{3}\right)$ dan variabel modal $\left(\mathrm{X}_{4}\right)$. dari keempat variabel di atas peneliti akan melihat seberapa besar pengaruh seluruh variabel yang paneliti gunakan dalam mempengaruhi variabel kesejahteraan (Y).

\section{Uji hipotesis}

\section{Uji bersama (uji F)}

Untuk mendapatkan hasil apakah variabel-variabel independen (pendidikan, tanggungan keluarga, hasil panen dan modal) yang di lakukan secara bersama memberikan pengaruh terhadap variabel dependen (kesejahteraan petani) dapat kita lihat hasilnya di tabel di bawah ini.

Tabel 2. Hasil pengujian secara bersama (uji f)

\begin{tabular}{lll|l|l|l|l}
\hline Model & Sum of Squares & df & Mean Square & F & Sig. \\
\hline $1 \quad \begin{array}{l}\text { Regression } \\
\text { Residual }\end{array}$ & $\begin{array}{l}13619621010000000.000 \\
2756120965000000.000\end{array}$ & 93 & 3404905252000000.000 & 114.892 & $.000^{\mathrm{b}}$ \\
Total & 16375741970000000.000 & 97 & & & \\
\hline
\end{tabular}

a. Dependent variable: $y$

b. Predictors: (constant), x4, x2, x1, x3

Sumber Data diolah, 2021

Kita lihat dari Tabel 2 merupakan hasil dari proses regresi linear berganda dapat kita perolah nilai Sig 0,000 lebih kecil dari 0,05 (nilai tolerir), dapat kita simpulkan bahwa Ho di tolak dan Ha di terima jika kita tafsirkan berdasarkan kriteria hasil yang di tetapkan maka kita dapat menarik kesimpulan bahwa variabel-variabel yang dipilih di antaranya pendidikan, jumlah tanggungan, hasil panen dan modal secara bersama-sama memberikan pengaruh signifikan kepada variabel Y (kesejahteraan petani padi).

\section{Pengujian terpisah (uji t)}

Sebelum ini kita melakukan pengujian secara bersama-sama atau yang kita kenal sebagai uji f yang memperolah hasil bahwa variabel-variabel yang digunakan berpengaruh signifikan terhadap kesejahteraan, maka selanjutnya peneliti akan 
melakukan pengujian secara terpisah (uji t) dalam melihat pengaruh antara variabelvariabel terhadap kesejahteraan petani padi dapat dilihat pada tabel dibawah ini.

Tabel 3. Hasil pengujian secara terpisah (uji t)

\begin{tabular}{llccccc}
\hline \multirow{2}{*}{ Model } & \multicolumn{2}{c}{ Unstandardized Coefficients } & $\begin{array}{c}\text { Standardized } \\
\text { Coefficients }\end{array}$ & \multirow{2}{*}{ t } & \multirow{2}{*}{ Sig. } \\
\cline { 2 - 5 } & $\mathbf{B}$ & Std. Error & Beta & & \\
\hline 1 & (Constant) & 14402185.880 & 2034871.662 & & 7.078 & .000 \\
\hline $\mathrm{x} 1$ & -113569.590 & 209587.479 & -.026 & -.542 & .589 \\
\hline $\mathrm{x} 2$ & -4360474.048 & 587055.360 & -.355 & -7.428 & .000 \\
\hline $\mathrm{x} 3$ & 22311.751 & 1697.305 & 1.197 & 13.145 & .000 \\
$\mathrm{x} 4$ & -.294 & .077 & -.344 & -3.835 & .000 \\
\hline
\end{tabular}

a. Dependent variable: $\mathrm{y}$

Sumber Data diolah, 2021

Berdasarkan Tabel 3 dapat kita intrepretasikan dalam bentuk terpisah di masingmasing variabel independet yakni pendidikan $\left(\mathrm{X}_{1}\right)$ tidak berpengaruh signifikan terhadap variabel Y dengan nilai Sig 0,589>0,05, maka dapat kita tarik kesimpulan bahwa Ho di terima Ha di tolak, Sedangkan Variabel jumlah tanggungan $\left(\mathrm{X}_{2}\right)$, hasil panen $\left(\mathrm{X}_{3}\right)$ dan modal $\left(\mathrm{X}_{4}\right)$ memiliki nilai Sig $0,00<0,05$ yang berarti Ho di tolak Ha diterima, dapat kita tarik kesimpulan bahwa variabel $\mathrm{X}_{2}, \mathrm{X}_{3}$, dan $\mathrm{X}_{4}$ bepengaruh signifikan terhadap variabel Y.

\section{Pengujian $\mathbf{R}^{2}$ (koefesien determinasi)}

Adapun tujuan dari pengujian $\mathrm{R}^{2}$ untuk melihat seberapa besar kemampuan model dalam menjelaskan variabel-variabel bebas yang digunakan. Kecilnya nya nilai Adjusted $\mathrm{R}^{2}$ menunjukan kemampuan variabel bebas dalam menjelaskan variabel terikat begitu terbatas. Nilai $R^{2}$ berada diantara 0 sampai $1\left(0 \leq R^{2} \leq 1\right)$, Jika nilai koefesien determinasi di atas 0,5 atau mendekati angka satu dikarenakan nilai $\mathrm{R}^{2}$ berada antara 0 sampai 1 maka bisa disimpulkan nilainya baik. Adapun dalam penelitian ini hasil dari nilai $\mathrm{R}^{2}$ dapat kita lihat dalam tabel di bawah ini.

Tabel 4. Hasil nilai $\mathrm{R}^{2}$ (koefesien determinasi)

\begin{tabular}{llllc}
\hline Model & R & R Square & Adjusted R Square & $\begin{array}{c}\text { Std. Error of the } \\
\text { Estimate }\end{array}$ \\
\hline 1 & $.912^{\mathrm{a}}$ & .832 & .824 & 5443868.96500
\end{tabular}

a. Predictors: (Constant), $\mathrm{x} 4, \mathrm{x} 2, \mathrm{x} 1, \mathrm{x} 3$

Sumber Data diolah, 2021

Dari Tabel 4 kita dapat menjelaskan bahwa nilai $\mathrm{R}^{2}$ sebesar 0,832 atau bisa kita persen kan dengan besar persen $83,2 \%$. Nilai dari hasil perhitungan bisa kita katagorikan besar dengan menunjukan hasil dari pengaruh variabel bebas (pendidikan, tanggungan keluarga, hasil panen dan modal) terhadap variabel terikat (kesejahteraan petani) sebesar $84,8 \%$ sedangkan sisa dalam menuju seratus persen berjumlah 16,8\% di pengaruhi oleh variabel-variabel yang tidak di gunakan dalam penelitian ini.

\section{Pengaruh pendidikan terhadap kesejahteraan petani padi}

Tingkat pendidikan petani yang tinggi disini mayoritas pada tingkat SLTA sehingga kurang memiliki pengaruh nyata terhadap peningkatan tingkat kesejahteraan 
petani, karena ketrampilan bertani mayoritas di pengaruhi oleh pengalaman petani itu sendiri, disini pendidikan tidak mempunyai jaminan dalam meningkatkan hasil panen yang melimpah hal ini terlihat pada hasil dari proses regresi yang menyatakan bahwa tingkat pendidikan tidak berpengaruh terhadap pendapatan petani padi di Kecamatan Air Hangat Timur, sedangkan untuk teknologi yang pakai tidak memiliki perbedaan antara yang tingkat pendidikan nya tinggi maupun yang rendah. Hal ini memiliki kesamaan terhadap hasil penelitian dari (Pranata et al., 2020) yaitu tingkat pendidikan tidak berpengaruh terhadap besarnya pendapatan yang di perolah. Selanjutnya juga mendapatkan hasil yang sama dalam penelitian (Juliansyah \& Riyono, 2018) Yang perlu di ketahui untuk petani yang menempuh pendidikan sangat minim dari yang memiliki latar belakang pendidikan bidang pertanian sehingga kalau masuk ke ranah nya yang sifatnya kerja di sawah yang berpendidikan tinggi belum memiliki pengalaman dalam mengolah serta memanfaatkan teknologi yang terbaru karena mayoritas petani tidak memiliki latar belakang pendidikan yang berbasis pertanian jadi tidak ada yang terlalu kreatif dalam mengembangkan atau mencari cara baru dalam mengelola usaha tani.

\section{Pengaruh jumlah tanggungan keluarga terhadap kesejahteraan petani padi}

Jumlah tanggungan keluarga sudah kita artikan di atas bahwa orang yang masih berada dalam suatu keluarga atau yang segala kebutuhannya masih di tanggung oleh suatu keluarga tersebut. Maka semakin banyak jumlah tanggungan keluarga maka semakin besar pula jumlah pengeluaran yang akan di keluarkan tentu hal ini sangat ditentukan dengan pendapatan yang diperolah. Jika tidak di ikuti oleh pendapatan yang besar dengan pengeluaran keluarga yang besar maka akan berdampak pada ketidak seimbangan ekonomi keluarga yang bermuara pada mendekatnya suatu keluarga ke garis kemiskinan.

Berdasarkan hasil dari olahan data maka dapat kita artikan bahwa jumlah tanggungan sangat mempengaruhi tingkat kesejahteraan, ini terbukti dalam peneilitianpenelitian sebelumnya bahwa menunjukan bahwa semakin bertambahnya jumlah tanggungan keluarga petani padi di Kecamatan Air Hangat Timur akan memberikan dampak negatif karena setiap adanya pertambahan tanggungan keluarga satu orang akan mengurangi kesejahteraan (pendapatan) petani sebesar 4.409.170 pertahunnya.

Kesejahteraan bisa menurun di akibatkan banyak nya pengeluaran dari induviduinduvidu dalam suatu keluarga, karena banyak tanggungan keluarga tanpa di iringi oleh tingkat pendapatan yang mempuni menjadi suatu perangkap kesejahteraan dari keluarga petani padi. Hal ini senada dengan penelitian (Sudrajat \& Isyanto, 2018) dan (Idayanti et al., 2019) dengan hasil yaitu menyatakan bahwa tanggungan keluarga memiliki pengaruh negatif terhadap kesejahteraan karena dengan bertambahnya jumlah tanggungan keluarga maka pendapatan akan berkurang dengan signifikan yang berdampak pada kesejahteraan.

\section{Pengaruh hasil panen terhadap kesejahteraan petani padi}

Dalam variabel hasil panen dalam hasil regresi yang sudah kita uraikan di atas dapat kita tarik beberapa maksud bahwa setiap penambahan hasil panen sangat berpengaruh terhadap kesejahteraan (pendapatan) karena hasil panen mentukan besarnya pendapatan yang akan di perolah. Jika hasil panen merosot tentu kan berimplikasi terhadap pendapatan yang diperolah olah petani, karena masyarakat di Kecamatan Air Hangat Timur menjadikan padi sebagai sektor andalan dalam menunjang perekonomian masyarakat tentu sangat mempengaruhi kesejahteraan dari besar kecilnya hasil panen yang di perolah.

Disini bisa kita melihat bahwa urgennya hasil panen dalam mendukung peningkatkan kesejahteraan petani, karena mayoritas pendapatan masyarakat Kecamatan 
Air Hangat Timur di dominasi oleh pendapatan dari usaha tani karena terlihat dari hari dalam pengeolaan usaha tani yang di kelola sendiri banyak di habiskan di tempat usaha tani yang di geluti, jika hasil nya merosot besar kemungkinan bahwa kesejahteraan akan menurun. Maka dalam pengelolaan usaha tani di harapkan untuk memaksimalkan setiap tahap pengelolaan agar memperolah hasil sesaui dengan yang di harapkan.

Hasil ini juga mempunyai kesamaan dengan hasil peneilitian dari penelitian (Alitawan \& Sutrisna, 2017), dengan hasil dapat disimpulkan bahwa semakin besarnya hasil panen yang di perolah maka pendapatan yang didapatkanpun samakin banyak dan begitupun sebaliknya.

\section{Pengaruh modal terhadap kesejahteraan petani padi}

Modal disini terdiri dari biaya-biaya yang di keluarkan dalam usaha tani yang di tekuni, dari hasil yang di perolah dalam proses olahan data dapat kita petik beberapa hasil yaitu setiap penambahan biaya-biaya dalam usaha tani berpengaruh terhadap pendapatan yang di perolah. Banyak nya biaya yang di keluarkan akan mengurangi pendapatan karena di Kecamatan Air Hangat Timur masih menggunakan teknologi yang sederhana tradional jadi biaya yang banyak tidak memberikan dampak positif terhadap pendapatan yang diperolah.

Jika modal di tambah dalam luas lahan yang tetap di setiap panen tidak akan menambah pendapatan hasil usaha tani (kesejahteraan), karena di Kecamatan Air Hangat Timur hampir mayoritas modal di gunakan untuk penambahan obat-obatan dan pupuk, tetapi petani di Kecamatan Air Hangat Timur hanya menggunakan pestisida maupun pupuk jika tanaman padi nya terserang hama atau mempunyai masalah dalam pertumbuhannya, yang terjadi dilapangan hal seperti ini sangat jarang ditemukan karena mayoritas tanah sawah yang ada di kecamatan air hangat timur masih relatif subur.

Disini dapat kita petik sebauh pelajaran bahwa biaya yang besar tidak menentukan seberapa banyak pendapatan yang di perolah maka seidealnya petani mampu mengefesienkan biaya-biaya setiap masa tanam usaha tani agar usaha tani yang ditekuni dapat memberikan keuntungan yang besar. Hasil dari penelitian ini memiliki kesamaan dengan penelitian dari (Alitawan \& Sutrisna, 2017) dengan Judul Faktor-Faktor Yang Mempengaruhi Pendapatan Petani Jeruk Pada Desa Gunung Bau Kecamatan Kintamani Kabupaten Bangli dan Phahlevi 2013. Faktor - Faktor Yang Mempengaruhi Pendapatan Petani Padi Sawah Di Kota Padang Panjang, yaitu semakin bertambahnya biaya yang di keluarkan maka keuntungan yang akan di peroleh semakin kecil.

\section{Implikasi Kebijakan}

Kesejahteraan merupakan suatu keadaan sosial ekonomi yang menetukan tingkat terpenuhinya kebutuhan rumah tangga di tengah masyarakat luas. Keberhasilan dari setiap pemerintah pasti bermuara kepada meningkatkan kesejahteraan masyarakat. Dalam rumpunya ilmu sosial, terkhusus bidang ekonomi di Negara sedang berkembang, sektor pertanian merupakan sektor yang paling utama serta paling banyak mendapat sorotan, hal ini bisa terlihat dari hasil-hasil peneilitian, artikel-artikel hingga pada tulisan-tulisan baik dalam ruang lingkup nasional hingga internasional terutama Indonesia masih berada dalam tahapan Negara sedang berkembang yang PDB nya masih di dominasi oleh sektor pertanian. Tentunya isu-isu bidang pertanian tidak henti-hentinya jadi trending topik hal banyak mengaitkan antara pertanian dan kemiskinan. Untuk pengambil kebijakan seharusnya dapat mempedomani hasil-hasil penelitian terkait sektor pertanian agar apaapa yang di tetapkan mampu berdampak secara signifikan terhadap masyarakat luas. 
Kabupaten Kerinci pada periode Bapak Adirozal (Bupati Kerinci) dalam (Pemerintah Kabupaten Kerinci, 2015) terdapat beberapa tujuan prioritas salah satunya meningkatkan pertumbuhan ekonomi yang berdampak langsung kepada seluruh lapisan masyarakat. Berbicara tentang pertumbuhan ekonomi tentunya kita langsung melihat pada pendapatan. Pendapatan masyarakat di Kabupaten Kerinci didominasi oleh pendapatan dari sektor pertanian, hal ini dikarenakan salah satunya yaitu tenaga kerja di sektor pertanian Kabupaten Kerinci mencapai angka 67,32\% dan juga jika kita merujuk kepada sumbangan sektor pertanian pada PDRB kabupaten kerinci dalam tiga tahun terakhir selalu berada di atas 50\%, dapat kita tarik kesimpulan lebih dari setengah masyarakat Kabupaten Kerinci bekerja dalam sektor pertanian dan juga lebih dari $50 \%$ ekonomi Kabupaten Kerinci bergantung pada sektor pertanian. Jika hal ini sudah kita ketahui secara bersama maka pemerintah sudah seharusnya memprioritaskan masyarakat setiap kebijakan yang di ambil yaitu dalam hal pertanian.

Dalam penjabaran misi-misi yang akan dilaksanakan oleh pemerintah Kabupaten Kerinci yang tertuang dalam RPJMD point nomor satu yaitu meningkatkan pendapatan daerah dan masyarakat yang berbasis pertanian hal ini sangat tepat, karena sektor pertanian diidentikan sebagai sumber pendapatan bagi masyarakat yang berada dalam keadaan prasejahtera. Maka dengan adanya prioritas perhatian terhadap sektor pertanian sudah bisa kita menarik gambaran bahwa pemerintah mempunyai keberpihakan kepada masyarakat yang berada dalam keadaan pra sejahtera dengan adanya meminimalisir ketimpangan pendapatan.

Pendapatan dalam masyarakat desa dengan basis pertanian merupakan faktor utama dalam meningkatkan kesejahteraan maka dalam penelitian ini untuk menentukan kesejahteraan indikator pendapatan lah yang menjadi tolak ukur hal ini sesuai dengan rumusan dari Direktorat Tata Guna Tanah dan juga menurut Sayogyo dalam mengukur tingkat kesejahteraan masyarakat. Dengan besarnya pendapatan yang di perolah oleh petani maka akan berdampak pada kebebasan dalam memilih setiap apa yang akan di kosumsi maupun jasa yang akan di gunakan hal ini dapat dengan mudah mencapai kepuasan yang menjadi tujuan masyarakat.

Berdasarkan hasil penelitian ini sumbangan pendapatan petani padi di Kabupaten Kerinci $70 \%$ berasal dari keuntungan usaha tani. Dari hasil penelitian ini dapat kita lihat besaran pengeluaran dalam mengelola usaha tani padi terletak pada biaya tenaga kerja dalam pengelolaan lahan mencapai $62 \%$ dari seluruh total biaya yang dikeluarkan, besarnya biaya yang dikeluarkan berpengaruh besar terhadap keuntungan yang diperolah dalam total pendapatan.

Seidealnya harus menjadi blue print bagi pemerintah dan pemangku kebijakan yang lain karena sebesar $62 \%$ biaya yang dikeluarkan oleh petani padi merupakan biaya tenaga kerja dalam pengelolaan lahan, disini diharpakan pemangku kebijakan untuk sensitif serta peka terhadap hal ini dengan berupa kebijakan teknologi dalam membantu mengefisieinkan pengeluaran biaya. Selama ini mungkin usaha ini telah ada diterapkan pemerintah tetapi mayoritas petani yang kami temui bahwa pembagian bantuan teknologi pertanian dibagikan secara tidak adil dan harus memberikan mahar terlebih dahulu. Ini bisa menjadi PR bagi pemangku kebijakan untuk menerapkan fungsi controlling mengontrol hingga pada objek penerima.

Berdasarkan hasil dari proses penelitian ini, dapat kita tarik kesimpulan secara umum bahwa keadaan petani di Kabupaten Kerinci Kecamatan Air Hangat Timur berdasarkan kriteria yang telah di tetapkan oleh Direktorat Tata Guna Tanah berada dalam 
keadaan tidak miskin dengan pendapatan perkapita berada di atas Rp. 4.487.400. dalam hal pendapatan seluruh keluarga petani dari seluruh pendapatan yang diperolah sekitar $70 \%$ berasal dari keuntungan usaha tani padi.

Memang pendapatan masyarakat di kabupaten Kerinci tidak semata-mata mengandalkan hasil dari usaha tani padi, masyarakat selain dari usaha tani padi juga memperolah pendapatan dari sektor bidang lain minsalnya kopi, tanaman sayuran, dan menjadi buruh tani ketika libur di sawah atau kebun sendiri. Jadi ada banyak sumber pendapatan dalam memenuhi kebutuhan sehari-hari masing-masing keluarga tidak hanya mengandalkan satu sektor saja.

Dalam mengukur tingkat kesejahteraan ada beberapa faktor penentu yang digunakan dalam penelitian ini terdiri dari beberapa variabel di antaranya pendidikan, jumlah tanggungan, dan modal yang digunakan dalam pengelolaan usaha tani. Dari analisis yang di lakukan dalam penelitian ini secara keseluruhan memperolah pengaruh yang signifikan terhadap kesejahteraan petani. Setelah di lakukan pengujian terpisah masing-masing variabel yang di gunakan mulai dari variabel pendidikan memberikan hasil yang tidak signifikan terhadap kesejahteraan hal ini jika dilihat dari hasil data yang di perolah dari kuisioner maka dapat di artikan bahwa mayoritas pendidikan petani di air hangat timur tidak menempuh jurusan yang serumpun dengan pertanian sehingga dalam melakukan pengelolaan sawah tetap mengikuti tradisi yang berlaku secara turun temurun, tidak kita temukan hal baru yang berupa teknologi dari petani yang memiliki pendidikan tinggi dalam meningkatkan hasil taninya.

Selanjutnya variabel yang diuji dalam penelitian ini yaitu variabel jumlah tanggungan memiliki pengaruh negatif signifikan, hal ini di sebabkan semakin bertambahnya jumlah tanggungan maka akan mengurangi kesejahteraan disebabkan semakin bertambah jumlah tanggungan maka jumlah pengeluaranpun ikut bertambah hingga pendapatan yang di peroleh semakin kecil. Seterusnya dilakukan variabel selanjutnya yaitu variabel hasil panen dengan memberolah hasil yang signifikan positif, hal ini dapat kita intepretasi bahwa semakin banyak hasil yang di perolah maka akan mendapat pendapatan yang besar hingga berpengaruh terhadap kesejahteraan petani. Terakhir variabel modal memiliki pengaruh negatif signifikan karena banyak nya modal yang di keluarkan memiliki pengaruh yang negatif karena lahan sawah di kabupaten kerinci masih dalam katagori yang cukup subur, jadi petani harus mampu mengefisienkan setiap pengeluaran dalam usaha tani agar keuntungan yang di perolah dari usaha tani lebih besar.

Dari hasil penelitian yang telah di paparkan diatas sudah nampak secara terang apa-apa yang perlu di tarik untuk di jadikan sebagai rujukan bagi pemerintah Kabupaten Kerinci dalam menetapkan strategi untuk meningkatkan kesejahteraan masyarakat lebih tepatnya masyarakat petani. Mulai dari variabel pertama bahwa tidak signifikannya pendidikan karena tidak singkronya pendidikan yang di tempuh dengan profesi yang dijalani, maka pemerintah sudah seharusnya mempunyai planning untuk mendirikan perguruan tinggi yang berbasis pertanian, menjelang itu pemerintah di harapkan untuk lebih meningkatkan anggaran penyuluhan pertanian kepada petani agar biaya modal yang di gunakan petani bisa lebih efisien dalam usaha pengelolaan usaha tani padi. Di samping itu pemerintah juga harus gesit dalam memperjuangkan subsidi sarana produksi tanaman padi mulai dari subsidi pupuk, bantuan alat-alat berteknologi (mesin bajak, traktor dan pestisida murah) hingga pada pembukaan lahan baru untuk membuka peluang bagi petani dalam mengatasi minimnya lahan yang di miliki. 


\section{KESIMPULAN DAN SARAN}

\section{Kesimpulan}

Pertama, Dalam menganalisis karakteristik sosial ekonomi petani padi di Kecamatan Air Hangat Timur Kabupaten Kerinci peneliti menyimpulkan dari hasil peneilitan bahwa petani padi rata-rata berusia 47 tahun dengan tingkat pendidikan ratarata telah menamatkan tingkat SLTP. Jika melihat dari luas lahan yang dimiliki petani padinya rata-rata mempunyai luas lahan yang dikelola sebesar 0,4 Ha dengan status ada yang disewa dan milik sendiri. Dalam mengelola usaha padi ini mayoritas sebesar $85 \%$ petani padi menggunakan benih milik sendiri jika hasil yang diperolah pada panen sebelumnya dikatagorikan berhasil. Sedangkan untuk tanggungan keluarga rata-rata petani padi di Kecamatan Air Hangat Timur berjumlah 2,4 orang. Kedua, Kesejahteraan petani padi di Kabupaten Kerinci Kecamatan Air Hangat Timur berdasarkan kriteria Direktorat Hak Guna Tanah dan kriteria kemiskinan Sayogyo diperolah hasil setelah dilakukan pengolahan data yaitu rata-rata petani padi di Kabupaten Kerinci Kecamatan Air Hangat Timur berada dalam kondisi tidak miskin berdasarkan dua indikator pengukuran diatas dengan pendapatan perkapita rata-rata Rp 5.053.227. Ketiga, Faktorfaktor yang mempengaruhi tingkat kesejahteraan petani padi yaitu diuraikan berdasarkan variabel yang peneliti pilih diantaranya pendidikan, jumlah tanggungan, hasil panen, dan modal. Dari keempat variabel yang digunakan ada satu variabel yang tidak signifikan yaitu variabel pendidikan, hal ini disebabkan diantaranya mayoritas pendidikan yang telah dilalui mayoritas petani tidak ada yang bersentuhan langsung dengan usaha tani padi. Selebihnya untuk ketiga variabel yang digunakan memperolah hasil yang signifikan terhadap kesejahteraan petani padi di Kabupaten Kerinci Kecamatan Air Hangat Timur.

\section{Saran}

Pertama, Pemerintah Kabupaten Kerinci di harapkan untuk selalu berpihak pada petani di samping mayoritas masyarakat di Kabupaten Kerinci berprofesi sebagai petani, minsalnya dalam hal perbaikan serta pemeliharaan infrastruktur dalam menunjang peningkatan pendapatan petani. Selama ini setelah dibangun uapaya pemeliharaan tidak begitu efesien karena infratrsuktur yang digunakan untuk keperluan akses petani jika kurang perawatan maka tidak akan tahan lama. Selanjutnya ketidakpastian harga beras yang membuat banyak petani mengalami kerugian dikarenakan salah satunya impor beras yang dilaksanakan pemerintah kedepannya pemerintah dalam meningkatkan kesejahteraan petani harus peka dengan hal tersebut. Kedua, Petani dalam mengelola lahan sawah dalam hal biaya yang dikeluarkan untuk dapat mengefisienkan terutama dalam hal biaya pestisida dan pupuk. Hal ini bisa terwujud jika petani mampu mendeteksi baik itu kebutuhan serta hama yang sedang menyerang tanaman padi. Maka diharapkan petani padi harus katif dalam mencari tau maupun ikut aktif dalam setiap penyuluhanpenyuluhan terutama dalam sektor pertanian dengan tanaman padi. Ketiga, Banyak nya modal yang di gunakan petani dalam hal upah tanaga kerja serta membeli pupuk dan pestisida maka di harapkan pemerintah mampu menyambut keluhan dari mayoritas masyarakat baik berupa dengan menganggarkan untuk subsidi pupuk, bibit unggul maupun hal yang menunjang keberhasilan petani dalam menekuni usaha taninya. Keempat, Bagi dinas terkait untuk jangan henti-hentinya memberikan penyuluhan praktis dalam pemanfaatan teknologi terbarukan maupun cara kreatif dalam mengelola lahan padi. Karena secara pendidikan petani padi di kecamatan air hangat timur tidak mempunyai basic secara linear dengan profesi yang di jalankannya, maka peran penyuluhan sangat urgen dalam meningkatkan kesejahteraan petani kedepannya. 


\section{DAFTAR PUSTAKA}

Alitawan, A. A. I., \& Sutrisna, K. (2017). Faktor-faktor yang mempengaruhi pendapatan petani jeruk pada desa gunung bau kecamatan kintamani kabupaten bangli. 796-826.

Budiarti, T., \& Muflikhati, I. (2013). Pengembangan agrowisata berbasis masyarakat pada usahatani terpadu guna meningkatkan kesejahteraan petani dan keberlanjutan sistem pertanian. Jurnal Ilmu Pertanian Indonesia, 18(3), 200207.

Dwijatenaya, I. B. M. A. (2017). Pendapatan dan kesejahteraan rumah tangga petani: studi kasus kelurahan bukit biru Kabupaten Kutai Kartanegara. GERBANG ETAM, 11(2).

Idayanti, P., Bakri, S., Wulandari, C., \& Yuwono, S. B. (2019). Karakteristik sosial ekonomi yang berpengaruh terhadap pendapatan kelompok hutan kemasyarakatan Panca Tunggal. Seminar Nasional Biologi 4 Bertema:Pemanfaatan Biodiversitas Dan Bioteknologi Untuk Pelestarian Lingkungan."

Juliansyah, H., \& Riyono, A. (2018). Pengaruh Produksi, luas lahan, dan tingkat pendidikan terhadap pendapatan petani karet di Desa Bukit Hagu Kecamatan Lhoksukon Kabupaten Aceh Utara. Jurnal Pertanian Ekonomi Animal, 1(2), 67.

Kementan. (2019). Kementerian pertanian republik Indonesia. https://www.pertanian.go.id/home/?show=news\&act=view\&id=3726

Pemerintah Kabupaten Kerinci. (2015). Rencana pembangunan jangka menengah daerah Kabupaten Kerinci Tahun 2014 - 2019 (Issue 0748, pp. 1-27).

Pranata, Y., Widjaya, S., \& Silviyanti, S. (2020). Analisis pendapatan dan tingkat kesejahteraan rumah tangga petani lada di Kecamatan Tanjung Raja, Kabupaten Lampung Utara. Jurnal Ilmu Ilmu Agribisnis: Journal of Agribusiness Science, 7(3), 383-390.

Sudrajat, S., \& Isyanto, A. Y. (2018). Faktor-faktor yang berpengaruh terhadap pendapatan usaha ternak ayam sentul di Kabupaten Ciamis. Mimbar Agribisnis: Jurnal Pemikiran Masyarakat Ilmiah Berwawasan Agribisnis, 4(1), 70-83.

Virianita, R., Soedewo, T., Amanah, S., \& Fatchiya, A. (2019). Farmers' perception to government support in implementing sustainable agriculture system. Jurnal Ilmu Pertanian Indonesia, 24(2), 168-177. 